\title{
Vzpomínka na hospodářské právo
}

\section{Economic Law}

\author{
Jarmila Pokorná*
}

\begin{abstract}
Abstrakt
Prüspèvek prèdstavuje osobni vąpominku na studium na právnické fakultè na prèlomu sedmdesátých a osmdesátých let 20. století. Zabývá se hospodárským právem jako speciálním predmètem, keterý byl na fakultè vyučován, a vapominá na učitele, keterí se mu vènovali.
\end{abstract}

\section{Klíčová slova}

Hospodárské právo; právnická fakulta; katedra hospodárského práva; zajimavé prednášky; osobni vzpominky; výjimečné osobnosti z dob našeho studia.

\begin{abstract}
The contribution presents a subjective memories of studies at the Faculty of Law in the seventies and early eighties of 20th century. It deals with economic law as one of special subjects, that were taugh at the faculty and remembers its teachers.
\end{abstract}

\section{Keywords}

Economic Law; Faculty of Law; Department of Economic Law; Interesting Lecture; Subjective Memories; Outstanding Personality of Our Studies.

\section{Úvod}

Letošní významné výročí, které slaví Masarykova univerzita, je též př́ležitostí k připomenutí složitého osudu její právnické fakulty. Necítím se povolána k tomu, abych k oslavám jubilejního roku přispěla odbornou historickou studií nebo vědecky zaměřnou esejí. Moje vzpomínka bude zcela subjektivní, bude vycházet z pocitů nadšené a trošku romantické maturantky, která se dostala na právnickou fakultu v podstatě z nouze a pro niž studium zde znamenalo první poměrně drsný střet s životem mimo rodinu i školní prostředí, v němž se až dosud pohybovala.

Moje studium na právnické fakultě nebylo výsledkem touhy po nalézání spravedlnosti či jiných ušlechtilých pohnutek, nýbrž bylo vedeno realistickou úvahou otce, který pochopil, že se pro prírodovědné obory nehodím, ale studium jazyků či historie nepovažoval za dobrý start do praktického života. Právnická fakulta představovala onen prijjatelný, z mého hlediska ale nezajímavý kompromis.

\footnotetext{
* Prof. JUDr. Jarmila Pokorná, CSc., Katedra obchodního práva, Právnická fakulta, Masarykova univerzita, Brno / Department of Commercial Law, Faculty of Law, Masaryk University, Brno, Czech Republic / E-mail: Jarmila.Pokorna@law.muni.cz / ORCID: 0000-0003-0350-5429
} 
Náš ročník nezahajoval studium v příznivých podmínkách. Byli jsme prvním zkušebním ročníkem, který se stal obětí reformačního úsilí, jehož jediným hmatatelným výsledkem bylo zkrácení doby studia na čtyři roky. Nutně muselo dojít ke změně organizace studia a k porušení logických návazností vyučovaných předmětů. To jsme ovšem jako nezkušení prvňáci vưbec netušili a dost možná to byla nevědomost uklidňující a pro nás i lepší. Fakulta, která byla tehdy umístěna na Zelném trhu v budově bývalé Cyrilometodějské záložny, působila navenek velmi okázale, avšak uvnitř se potýkala s prostorovými problémy, neměla pořádnou posluchárnu pro přednášky, seminární učebny byly vytvořeny z bývalých bytů, v knihovně se nedalo studovat, sloužila jen jako pưjčovna studijních materiálů. Chyběly učebnice, skripta byla nedostatková a složitě se půjčovala, kopírovala, dokonce opisovala, o audiovizuální technice jsme si mohli nechat jen zdát. Veškerou technickou vymožeností byla tabule a křída, a když byl vyučující zvláště vynalézavý, používal křídy barevné. Prvním a nezapomenutelným zážitkem z kontaktu s fakultou byly úklidové práce, při nichž jsme poznali nikoli učebny, ale místa spíše nevábná, náležející k provoznímu zázemí budovy.

První ročník studia začínal historickými předměty, na něž jsem se docela těšila, protože historie byla a dodnes zůstala mým velkým koníčkem. Úvodní historické disciplíny mě však rychle vyvedly z nadšení. Nutně jsem je musela vnímat konfrontačně - bylo zajímavé srovnávat obsah a styl jejich výuky s dějepisem na gymnáziu. Je však nutno podotknout, že naše gymnaziální výuka historie neopomíjela historické drby a klevety, byla prŕležitostně doprovázena písněmi, pověstmi a vtípky a kořeněna značnou dávkou studentské recese, do níž se náš vyučující profesor rád zapojoval, takže je jasné, kdo vyšel z oné konfrontace jako vítěz. Přece však existovala jedna výjimka - předmět se jmenoval Všeobecné dějiny státu a práva a jméno přednášejícího, Valentin Urfus, nás tehdy fascinovalo stejně jako obsah přednášek. Byl to první okamžik, v němž převážná většina ročníku pocítila, jak vypadá opravdová vysokoškolská přednáška pronášená zpaměti, s jasnou strukturou, vysvětlením přednášených událostí, nalézáním souvislostí a jejich významu pro další vývoj daného území i Evropy. Tento předmět zůstal pro mě bohužel jediným světlým okamžikem prvního ročníku studia, nebot’ letní semestr naplněný tzv. dějinami socialistického státu a práva obdobné duševní potěšení ani zdaleka neposkytoval. Na pana profesora Urfuse jsem si po mnoha letech s vděčností vzpomněla, když jsem v Mahenově knihovně narazila na jeho studii o Josefu I. napsanou týmž jasným a logickým způsobem, který jsme tak dobře znali z jeho přednášek.

Celkový dojem z prvního ročníku nebyl tedy nijak optimistický, ale doufala jsem, že změnu přinese výuka toho skutečného práva, jednotlivých právních odvětví. Očekávání však opět nebyla naplněna. Reformovaný program studia nám jako jeden z prvních pozitivních oborů prínesl správní právo, které mě nejen nezaujalo, ale svým rozsahem naprosto vyděsilo a uvedlo do stavu rezignované apatie. Když se proto objevil na rozvrhu předmět nesoucí název hospodářské právo, říkala jsem si, no budiž, nic už mě nemůže překvapit. 
Přišel však ten velmi vzácný okamžik, který mění osudy lidí a události obrací v jejich naprostý opak.

\section{Hospodářské právo}

Hospodářské právo bylo v polovině sedmdesátých let minulého století odvětvím, které si po složitých diskusích vydobylo postavení samostatného právního oboru. Mohli bychom je označit s jistou nadsázkou jako právo regulující vztahy vznikající při provozování ekonomických aktivit, které dnes nazýváme jednoduše podnikáním. O žádné podnikatelské činnosti v dnešním slova smyslu samozřejmě nešlo, hospodářství se vyvíjelo podle krátkodobých, střednědobých a dlouhodobých plánů, které určovaly, jakých výsledků má být dosaženo a takto stanoveným cílům podřizovaly využití veškerých materiálních zdrojů i lidskou tvořivost.

Základem hospodářství byly podniky, pro něž byl používán termín státní socialistické organizace a které hospodarily s majetkem ve státním socialistickém vlastnictví. Sama existence podniků, které byly z hlediska právního nadány právní subjektivitou, závisela na rozhodnutí př́slušných orgánů hospodářského řízení, jimž příslušelo oprávnění určovat zaměření činnosti podniků, plánovitě rrídit tuto činnost (tj. ukládat podnikům úkoly, rozhodovat o investicích většího rozsahu apod.) a činit určité, přesně vymezené dispozice s majetkem podniků. Podniky byly povinny odvádět stanovené částky do státního rozpočtu, mohly samostatně rozhodovat o běžných věcech týkajících se jejich hospodaření, ale od právní regulace se čekalo, že stanoví pevné bariéry znemožňující, aby se podniky fakticky staly skupinovými vlastníky a ve svém rozhodování se řídily jen vlastními zájmy na úkor zájmů společnosti. ${ }^{1}$

Koncepce socialistického společenského vlastnictví, do něhož patřily všechny ekonomicky využitelné zdroje na straně jedné, a osobního vlastnictví spojeného s občany a určeného k uspokojování jejich potřeb na straně druhé, se promítala i do dobových diskusí o odvětvové samostatnosti hospodářského práva. Výsledkem těchto diskusí bylo potom chápání československého socialistického občanského práva jako odvětví, které upravuje majetkové, a to zbožně peněžní vztahy, vznikající přri výstavbě rozvinuté socialistické společnosti jednak v procesu uspokojování osobní spotřeby občanů, jednak v zahraničním obchodě, dále osobně majetkové vztahy a konečně ryze osobní vztahy, pokud se ve všech těchto vztazích uplatňuje princip právní rovnosti jejich účastníků. Z komplexu občanskoprávních vztahů byly vyjmuty hospodářské vztahy mezi socialistickými organizacemi a socialistické vlastnictví, které se považovaly za předmět úpravy hospodářského práva. Rozdíl mezi hospodářským právem a občanským právem byl spatřován v kvalitě a sociálním poslání hospodářským právem upravovaných majetkových vztahů, které se mezi socialistickými organizacemi při koordinaci jejich činnosti

1 ČAPEK, K. Práuni postaveni socialistických podnikư. Praha: ACADEMIA, 1976, s. 53-54. 
a výkonu socialistického společenského vlastnictví uskutečňovaly v rámci zákona plánovitého rozvoje socialistického národního hospodářství. ${ }^{2}$

Přeloženo do lidského jazyka - občanské právo bylo chápáno zúženě jen jako právo regulující postavení občanů v majetkových vztazích sloužících potrebám jejich života, popř. sem bylo řazeno i právo autorské. Pramenem této právní regulace byl občanský zákoník, z. č. 40/1964 Sb. Regulace hospodářské činnosti socialistických organizací byla z občanského práva vyčleněna, tvořila obsah samostatného právního odvětví, hospodářského práva, jehož základním pramenem byl z. č. 109/1964 Sb., hospodářský zákoník, který tudíž neměl žádnou systematickou souvislost se zákoníkem občanským, byly to dvě oddělené oblasti s odlišným věcným obsahem. Je ovšem nutno zdůraznit, že hospodářský zákoník jako právní předpis regulující vztahy vyplývající ze socialistického společenského vlastnictví byl použitelný toliko uvnitř ČSSR. Pokud se mělo na základě předpisů mezinárodního práva soukromého použít na hospodářské vztahy s mezinárodním prvkem československého právního řádu, byl výchozím pramenem z. č. 101/1963 Sb., zákoník mezinárodního obchodu, který měl nejblíže k tradičnímu občanskému právu a byl určen především pro regulaci obchodního styku s cizím prvkem představovaným podnikateli z té části světa, která byla označována jako kapitalistická. ${ }^{3}$

Již z tohoto krátkého popisu musí být jasné, že hospodářský zákoník byl svérázným právním předpisem, který se snažil propojit oheň a vodu, když i v prostředí prŕsného centralistického řízení a př́mých státních zásahů do ekonomiky poskytoval určitý prostor pro smluvní autonomii a vlastní rozhodování socialistických hospodářských organizací. Obsahoval proto prvky, které bychom mohli dnes přiřadit spíše k právu soukromému a které měly nejblíže k regulaci na smluvním základě, a to v kombinaci s prvky př́mých státních zásahů, které byly jednoznačně veřejnoprávní povahy. Př́ikladem takového státního zásahu byly tzv. plánovací akty, v podstatě rozhodnutí př́slušných ministerstev zakládající dodávkovou povinnost.

Kromě úpravy zmíněných druhů právních skutečností obsahoval hospodářský zákoník i základní úpravu organizace hospodářských činností v tzv. výrobních hospodářských jednotkách, do nichž se spojovaly oborové, národní a koncernové podniky jako právně organizační formy pro realizaci výroby a obchodování. Úroveň příslušné výrobní hospodářské jednotky reprezentovala tzv. střední článek řízení převádějící centrální

2 ČAPEK, K. Předmèt a systém československého hospodárského práva. Praha: ACADEMIA, 1984, s. 246-247; Autor publikace cituje učebnice Ceskoslovenské občanské právo. Svazek I. Praha, 1974, s. 20; a Ceskoslovenské občanské právo, I. Praha, 1982, s. 13, 15-16.

3 Soustavu pramenů mezinárodního práva soukromého v té době popisuje KUČERA, Z. v učebnici Mezinárodni právo soukromé. Praha: Orbis, 1975, s. 30 a násl. 
rozhodování na úrovni ministerstev do denní praxe řízených organizací. ${ }^{4}$ Dalšími organizačními formami pro provozování ekonomických aktivit byla družstva, která měla ovšem svou speciální právní úpravu a z hlediska výuky byla páteří samostatného předmětu, který nesl označení zemědělskodružstevní a pozemkové právo.

Hospodářským zákoníkem soustava pramenů hospodářského práva zdaleka nekončila. Nejvýznamnějšími prováděcími předpisy k hospodářskému zákoníku byly tzv. základní podmínky dodávky vydávané př́íslušnými dodavatelskými ministerstvy na úrovni federace či jednotlivých republik a upravující to, co dnes tvoří obsah smluv, popř. obchodních podmínek. Tyto předpisy měly převážně kogentní povahu, neposkytovaly velký prostor pro smluvní autonomii jednotlivých podniků, na druhé straně však zjednodušovaly obchodní styk a poskytovaly značnou míru právní jistoty.

V zájmu historické spravedlnosti je nutno ještě zmínit procesní stránku věci. Hospodářské spory $\mathrm{v}$ té době nerozsuzovaly soudy, ale zabývala se jimi zvláštní soustava státních orgánů, která nesla označení státní arbitráž. Jejím základním článkem byly krajské státní arbitráže obsazené několika státními arbitry, jejichž počet závisel na hospodářské vyspělosti př́islušného kraje. Jen pro představu - státní arbitráž sídlící v Brně patřila z tohoto pohledu k těm nejvýznamnějším, ovšem i zde se počet státních arbitrů pohyboval okolo jedné desítky. Základním procesním předpisem byl z. č. 121/1962 Sb., o hospodářské arbitráži, obsahující velmi jednoduchá a neformální procesní pravidla, která však v praxi fungovala velmi dobře a umožňovala rychlý postup k podstatě sporu a jeho efektivní vyřešení.

Je jasné, že pro převážnou většinu posluchačů druhého ročníku bylo všechno toto výše zmíněné opravdovou španělskou vesnicí, do níž vstupovali s úžasem či odporem podle toho, nakolik byli ochotni ponořit se do ekonomických otázek. Výhodu měli samozřejmě absolventi ekonomických středních škol. Je též jasné, jak obtížná byla úloha učitele, který měl celý tento složitý systém vysvětlit, a to pokud možno zajímavě a názorně, aby posluchači pochopili, jak spolu jednotlivé prvky souvisejí a jak fungují.

A zde jsme se podruhé za našeho relativně dosud krátkého pobytu na fakultě setkali s výukou, kterou bychom bez rozmýšlení označili jako vysokoškolskou. Stála za ní osobnost dodnes vědecky a pedagogicky činná, právník, učitel, autor vědeckých studí i vtipných fejetonů, prof. JUDr. Petr Hajn, DrSc. Každý, kdo někdy zažil jeho přednášku,

4 Výrobní hospodářské jednotky (VHJ) byly organizovány bud' jako oborové podniky podřizené přímo ministerstvu vnitřně členěné na závody bez právní subjektivity, nebo jako trust podniků, který sdružoval právně samostatné národní podniky disponující právní subjektivitou. Na úrovni trustu byly soustředěny činnosti, jejichž zajišt'ování v jednotlivých podnicích nebylo účelné, např. zásobování dováženými surovinami. Zvláštní formou byl potom koncern, který se skládal z jednotlivých koncernových podniků. Subjektem práva byl koncern jako celek, koncernové podniky byly jeho pouhými organizačními jednotkami, mohly však v rozsahu vymezeném předmětem činnosti koncernu vyvijet samostatnou hospodářskou činnost. Podrobnější úprava VHJ nebyla již obsažena v hospodářském zákoníku, nýbrž byla svěřena prováděcímu předpisu - vl. nař. č. 91/1974 Sb., o organizaci VHJ a jejich statutech. 
si musí přiznat, že byl vtažen do vysvětlovaného problému, někdy dokonce i proti své vůli. O přednáškách z hospodářského práva obecně platilo, že byly jasné a srozumitelné, vysvětlovaly jednotlivé problémy, upozorňovaly na širší souvislosti probíraných témat a využívaly názorných př́kladů. Přednášející byl ovšem mistr slova a dovedl opanovat bojiště. Při přednášce se opíral toliko o text právního předpisu a formuloval poučení, argumenty i závěry bezprostředně přímo na místě. Přednáška tak mnohdy získávala charakter přímo divadelního představení či detektivního románu, v němž posluchači s napětím očekávali, jaké rozuzlení jim přednášející připraví. Uvážíme-li, že předmětem přednášky byly výrobní hospodářské jednotky, penále za prodlení či předání a převzetí dodávky pro investiční výstavbu a že kromě mluveného slova nebyly používány žádné další technické pomůcky a zařízení, lze tomu dnes jen stěží uvěřit.

S osobností přednášejícího bylo spojeno několik do té doby nevídaných novinek: mohli jsme, ba museli jsme mít na přednášce text př́slušného právního předpisu, tehdy hospodářského zákoníku. Sledovat přednášku znamenalo být neustále ve střehu, zvládnout rychle systematiku zákoníku a pronikat do významu jeho textu, protože přednášející volně procházel mezi řadami stolů, u nichž jsme v různých polohách skrčenců seděli, ${ }^{5}$ a svoje úvahy a vysvětlující poznámky prokládal otázkami, s nimiž se na nás obracel. Bylo příznačné, že naše nepř́liš vynalézavé odpovědi hodnotil jako zajímavá stanoviska, nezapomínal ale dodat, že možná by bylo lepší, kdybychom se na problém podívali ještě z jiné stránky. Tato jiná stránka byla samozřejmě ta správná a vedla ke správnému řešení. I jen průměrně inteligentní posluchač se musel ve svém nitru zastydět, že na tak očividnou věc nepřišel sám, nicméně prŕíslušné pravidlo chování si velmi dobře zapamatoval. Výsledkem této metody výuky byla velmi slušná znalost systematiky i textu zákoníku, schopnost vyložit smysl a funkci všech jeho podstatných částí i jednotlivých norem. Učili jsme se tak mimoděk nejen normativnímu obsahu, ale i metodám, jak dospět k jeho interpretaci, to vše zcela nenásilně a velmi efektivně.

Z dnešního pohledu bylo též velmi zajímavé, jak se vyučující vyrovnával s přítomností oněch protikladných živlů - prvků volní autonomie v tuhém centralismu. Právní vztahy vznikající v tomto prostředí nám byly demonstrovány jako diagonální - nikoli čistě vertikální, jak by se dalo při centrálním plánování čekat, ale také ne čistě horizontální. Př́kladem by mohly být tzv. majetkové sankce, označované též jako penále, vzdálený př́buzný dnešních smluvních pokut. Na rozdíl od nich byly ale jejich sazby i způsob výpočtu upraveny v zákoně a jejich uplatnění bylo právní povinností. Tedy něco jako kř́ǐženec šelmy s býložravcem, který ovšem ve své době představoval zcela vážný praktický i teoretický problém. Zatímco teorie řešila záludnou otázku, proč ty povinné majetkové sankce nemají vůbec žádný vliv na včasnost a kvalitu dodávek, byla praxe mnohem zajímavější. Poznala jsem to okamžitě po svém nástupu na právní oddělení jednoho

5 Přednášky se z prostorových důvodů nekonaly na fakultě, ale v sále tehdy obvodního vzdělávacího stř̌ediska v Husovicích na Musilově ulici. 
z tehdejších brněnských textilních podniků, nebot' mi moje vedoucí prridělila vyřizování právních problémů vznikajících při penalizaci za prodlení s dodávkami. Byla to opravdová škola života, v níž jsem poznala okouzlující bytost v osobě penalizační referentky, paní Vlasty Chlupové. Ředitelství podniku i všechny výrobní závody znala dokonale a při počítání penále mě nenápadně uvedla do světa, v němž odbytoví referenti uzavírali smlouvy, vedoucí skladů evidovali dodávky a pracovníci ekonomického útvaru vystavovali faktury. Všichni měli samozřejmě svůj svébytný systém evidence dodávek, takže dohledávání opožděně dodaných množství byla malá detektivní hra. Hrála jsem ji však se zaujetím a nejednou jsem ocenila př́pravu, kterou jsem studiem na fakultě pro tuto činnost získala. Vrátíme-li se však zpět $\mathrm{k}$ výuce hospodářského práva, nemohu nevzpomenout, že se kromě vlastního hospodářského práva dostalo studentům v rámci přednášek i dalšího poučení, které by dnešní vědci v oboru pedagogiky označili jako výchova k postojům a hodnotám. Dověděli jsme se například, že při smluvním vyjednávání není dobré zdeptat protivníka, ovládnout jednací pole a vnutit takto partnerovi vlastní výhodné podmínky. Pro budoucí korektní vztahy je mnohem lepší z vlastních pozic poněkud ustoupit a dopřát partnerovi iluzi mírné převahy. Poučení, které na přednášce vyznělo jako vtipná ironie určená pro osvěžení publika, bylo velmi praktické a později jsem je nejednou použila při řešení sporů o vady zboží nebo prodlení s dodávkami. Obdobně praktický smysl mělo i upozornění na skutečnost, že každé řešení má svou omezenou platnost, protože „v běhu času je skryto mnoho nadějí“. Výchovu k trpělivosti a prozíravosti jsem docenila též až za mnoho let, kdy mi za úplně jiných okolností, než byla aplikace práva, doslova zachránila život. Rovněž jsme se učili, jak důležitá je vlastní aktivita - „kedyž nebudete na dvere klepat, nikdo vám neotevré, když ale klepat budete, je velmi pravdèpodobné, že se jednou ony dvere otevrou". V dnešních podmínkách výchovy k sebevědomí spíše přebujelému zní toto nabádání velmi krotce, $\mathrm{v}$ polovině let sedmdesátých minulého století to však byl přístup ojedinělý a překvapivý.

Další nevídanou věcí byl postup při zkoušce z hospodářského práva. Vedoucí katedry si pozval vždy současně tř́ až čtyři studenty, kterým v otázce předložil nějaký problém, k němuž se vyjádřil nejprve první zkoušený a další měli jeho odpověd’ korigovat a doplňovat, popř. odpovědět sami, pokud první posluchač správné řešení neznal. Dialog, který se takto rozvinul, odhalil velmi přesně hlubiny našich neznalostí, byl však př́iznivý pro ty, kteří prokázali schopnost rychlého myšlení a dovedli předložit netradiční, ale tvưrčí úvahu. Smysl studia jako by se najednou změnil. Již nebylo nutno nastěhovat do mozku obsah skript a přednášek, pokud možno doslova, ale primárním se stal smysl, funkce, význam př́islušných pravidel chování. Zkušební otázka se přestala pídit po tom, co právní předpisy obsahují, ale ptala se, proč tomu tak je. Bylo by ale mylné domnívat se, že se tím zkouška stávala pouhým řečnickým cvičením, při němž bylo možno uplatnit cokoli, co mozek týraný zkušebními okolnostmi právě vyplivl. Myšlenky zkouškově významné se mohly urodit jen jako výsledek pečlivé předchozí prŕpravy. 
Náš přednášející vedl katedru sdružující obory související s hospodářstvím, dnes bychom řekli související s podnikáním. Patřilo sem kromě práva hospodářského i právo pracovní, zemědělskodružstevní a pozemkové, později i právo finanční a též ekonomické obory - národní hospodářství a úsekové ekonomiky. Katedra byla posměšně označována jako „katedra veškerého práva“ či „,katedra s dlouhým názvem“, to mě ovšem tehdy nezajímalo. Jako studentka druhého ročníku jsem oceňovala, že vedoucí katedry svěřil seminární výuku vynikajícím praktikům, vedoucím právních oddělení velkých brněnských podniků, kteři samozřejmě ku prospěchu věci často opouštěli pole ryze akademická a zprŕístupňovali studentům drsnou praxi právníka činného v hospodářské sféře. Naši seminární skupinu učil JUDr. Jan Vích, CSc., vedoucí právního odboru v Cheposu, podniku, který tehdy náležel k největším vývozcům technologických celků pro chemický průmysl a rafinerie. Poznala jsem v něm nesmírně aktivního člověka, jenž přicházel vždy s novými myšlenkami a znepokojivými dotazy. Mnohem později, když jsem již pracovala na fakultě, jsem se vždy těšila na jeho pozdrav „Nazdar hošové“, se kterým vstupoval do kanceláře a který zahrnoval nejen mé dva kolegy, ale i mě, jsem chápala vzdor všem feministickým poučkám jako svým způsobem vyznamenání.

Ještě jednu epizodu, prokazující, jak tvořivé prostředí na oboru hospodářského práva panovalo, považuji za důležitou. Jak jsem již na počátku podotkla, byly technické prostředky používané při výuce vynalezeny již za Marie Terezie. Na konci sedmdesátých let a v letech osmdesátých se však začínaly objevovat první náznaky existence výpočetní techniky a začínalo se mluvit též o tom, že by mohly být ve výuce využity audiovizuální pomůcky. V té době jsem již po návratu na fakultu byla zaměstnána na oné „katedře s dlouhým názvem“ a mohla jsem být svědkem události, která se asi už opakovat nebudenatáčení výukového filmu. Film byl hoden svého charakteru propojujícího viděné se slyšeným a vyprávěl příběh jednoho reklamačního sporu o vlastnosti chemikálií používaných pro vyvolávání fotografií. Zápletka spočívala $v$ tom, že chemikálie byly spečené do hroudy, kterou nebylo možno sypat a odměřovat tak potřebné množství chemikálie. Dodavatel tvrdil, že je vše v pořádku, nebot' dodal smluvený druh chemikálie a o jejích dalších vlastnostech smlouva ničeho neurčovala, odběratel se oháněl vlastnostmi obvyklými a poukazoval na to, že není povinen roztloukat hroudy, aby mohl vyvolat fotografie. Spor ve filmu posuzoval skutečný arbitr krajské státní arbitráže a výsledek zdůrazňoval význam oněch obvyklých vlastností. Už si opravdu nevzpomínám, zda a kolikrát jsme uvedené dílo použili ve výuce, ale sama prríprava natáčení, jeho průběh a zaujetí, s nímž se všichni do tohoto projektu zapojili, mi zůstaly v paměti dodnes.

\section{Závěrem}

Zaujetí, které bylo spojeno s výukou hospodářského práva, mělo na mě ten pozitivní vliv, že jsem přestala chápat svoje studium na právnické fakultě jako něco, k čemu jsem byla donucena okolnostmi a vlivem rodičů a začala jsem je brát s větší vážností. 
Bez nadsázky mohu dnes říci, že mě hospodářské právo a zpơsob jeho výuky otevřely cestu k ostatním právním odvětvím a právnickému studiu jako takovému. Ujasnila jsem si, že bude asi dobré fakultu dokončit a přemýšlela jsem o tom, že patrně budu po ukončení fakulty hledat svoje praktické uplatnění v podnikové sféře. I když sil a nadšení ke konci studia značně ubývalo a některé předměty, které u mých spolužáků vzbuzovaly nadšení (např. mezinárodní právo veřejné), byly pro mě stěží pochopitelné (říkala jsem si např., že jen nenapravitelný optimista může doufat v to, že se ve válce budou dodržovat pravidla pro zacházení s válečnými zajatci), podařilo se mi pochybnosti překonat, studium dokončit a najít si práci v již zmíněném textilním podniku. Musím konstatovat, že mi přechod do praxe neprripravil nějaká zvlášt’ záludná překvapení. Výuka hospodářského i pracovního práva, disciplín, které jsem používala nejčastěji, byla na fakultě při zpětném pohledu z praxe na velmi dobré úrovni a bylo nutno jen zvládnout vnitropodnikové předpisy, normy a zvyklosti a poznat samožrejmě vnitřní organizaci podniku a náplň práce jednotlivých útvarů, aby byl absolvent fakulty schopen na právním oddělení vyřizovat nejběžnější typy prrípadů.

Za několik let mě ovšem začalo pálit dobré textilní bydlo a začala jsem sondovat, zda by se neotevřela nějaká možnost návratu na fakultu. A zde nastal okamžik, v němž se uplatnila všechna dřívější poučení o nadějích skrytých v čase i o dveřích, na něž je nutno klepat. Možnost návratu se skutečně naskytla a začalo další dějství mého soužití s hospodářským právem, ted’ ovšem již ve zcela jiné roli.

$\mathrm{Na}$ fakultu jsem již nepřicházela jako romantický maturant, ale jako absolvent, jehož nadšení sice praxe usměrnila, nicméně nezničila. Bylo tedy velmi důležité, zda se zvědavé očekávání změní v tvưrčí práci, nebo zda bude udušeno každodenní rutinou. Při zpětném pohledu je jasné, že moje rozhodnutí vrátit se na fakultu bylo správné, což ovšem nebyla moje zásluha, nýbrž následek št’astných okolností spočívajících zejména v prátelském prostředí, které na katedře s dlouhým názvem panovalo.

Bylo by již zcela jinou kapitolou této vzpomínky, kdybych měla popisovat pracovní atmosféru katedry, mohu-li ale doplnit svoje předchozí vzpomínky studenta, musím zmínit své nové kolegy a prof. Hajna jako vedoucího katedry. Bylo velmi obtížné zvyknout si na to, že svoje někdejší učitele potkávám nyní v pozici spolupracovníka, jejich př́stup ke mně i poměry panující na katedře mi však pomohly rozpaky rychle překonat. Katedra byla vedena neformálním, velmi demokratickým stylem, který podněcoval k dalšímu studiu nejen zvoleného oboru, ale i k jazykové př́ípravě, což se v normalizačních letech zdálo být zcela zbytečným. Mimochodem - studenti v těchto letech nejvíce protestovali vedle tělocviku právě proti jazykové výuce. Pokud to omezené možnosti dovolovaly, stimuloval nás vedoucí katedry k pobytům v zahraničí i k aktivitám, které s právem zdánlivě nesouvisely, ale rozšiřovaly všeobecné vzdělání. Bylo to spojeno s dalším ponaučením o tom, že dobrý právník nemůže být „fachidiot“، tedy úřední šiml řehtající jen podle not právního předpisu. 
Stojím-li tedy dnes na konci svého profesionálního života, uvědomuji si, jak velkou a št'astnou náhodou mi bylo dopřáno poznat všechny spolupracovníky, kteří v osmdesátých letech minulého století tvořili kolektiv naší velké katedry a po letech prožitých v podnikové praxi mi pomohli při vstupu do akademického světa. Patř́ jim moje velké a upřímné poděkování, i když pro řadu z nich již přichází opožděně.

Tato drobná vzpomínka budiž současně poděkováním prof. JUDr. Petru Hajnovi, DrSc., učiteli našeho ročníku a dlouholetému vedoucímu katedry, za moudrost, která ovlivnila profesionální i lidské cesty mnohých z nás. 